\title{
Prey selection, ingestion and growth responses of the common marine ciliate Mesodinium pulex in the light and in the dark
}

\author{
Woraporn Tarangkoon ${ }^{1,2}$, Per Juel Hansen ${ }^{1, *}$ \\ ${ }^{1}$ Marine Biological Laboratory, Strandpromenaden 5, 3000 Helsingør, Denmark \\ ${ }^{2}$ Faculty of Science and Fisheries Technology, Rajamangala University of Technology Srivijaya, 92150 Trang, Thailand
}

\begin{abstract}
We studied the prey selection and feeding physiology of a non-symbiotic-containing ciliate Mesodinium pulex (Class Litostomatea). In an experiment to test feeding and growth with a variety of prey, M. pulex ingested all 5 species of cryptophytes and the autotrophic dinoflagellate Heterocapsa rotundata offered as food. Despite this, it only grew on the cryptophytes Teleaulax sp. and Guillardia theta and the dinoflagellate, because ingestion rates of the other prey cells, even at very high prey concentrations, were too low to support growth. The numerical and functional responses of M. pulex fed $H$. rotundata were investigated in the laboratory in the light $\left(100 \mu \mathrm{mol}\right.$ photons $\left.\mathrm{m}^{-2} \mathrm{~s}^{-1}\right)$ and in the dark. In the light, the growth rate was significantly higher than in the dark at all prey concentrations. Active photosynthesis was measured in $M$. pulex but our rates could not explain the increased growth rates in the light, which, instead, were mainly explained by elevated ingestion rates. We also studied the starvation response at irradiances of 100 and $50 \mu \mathrm{mol}$ photons m $\mathrm{m}^{-2} \mathrm{~s}^{-1}$ and in the dark. $M$. pulex survived for up to $2 \mathrm{wk}$ without food, but mortality rates in the light were higher than in the dark.
\end{abstract}

KEY WORDS: Mesodinium pulex $\cdot$ Growth $\cdot$ Ingestion $\cdot$ Ciliate

\section{INTRODUCTION}

The ciliate genus Mesodinium (Stein 1863) belongs to the Order Cyclotrichiida (Class Litostomatea; Lynn 2008). Presently, the genus includes the red M. rubrum (Lohmann 1908) Hamburger \& von Buddenbrock 1911 (= Myrionecta rubra), which forms symbiosis with cryptophytes belonging to the Teleaulax/Geminigera clade (e.g. Garcia-Cuetos et al. 2010) and 6 species without symbionts: $M$. pulex Claparède \& Lachmann 1858, 1859, $M$. acarus Stein 1867, M. fimbriatum Stokes 1887, M. cinctum Calkins 1902, M. pupula Kahl 1935, and M. velox Tamar 1986.

Mesodinium acarus, $M$. fimbriatum and $M$. pulex have all been observed in freshwater, but at least $M$. acarus and $M$. pulex have also been observed in brackish and marine waters (e.g. Foissner et al. 1999). The remaining species are commonly found in brackish and marine waters (Lindholm 1985, Foissner et al. 1999). Recently, Bass et al. (2009) reported that clones identified as $M$. pulex fall into 2 different phylogenetic clades, indicating the existence of additional undescribed species.

Our knowledge of which diet supports the growth of Mesodinium spp. derives mainly from studies of $M$. rubrum and $M$. pulex. $M$. rubrum has been shown to ingest many different species of cryptophytes (Gustafson et al. 2000, Yih et al. 2004, Park et al. 2007, P. J. Hansen et al. unpubl.). However, it can also feed on other types of prey (i.e. a dinoflagellate; P. J. Hansen et al. unpubl.). Despite this, successful cultures of $M$. rubrum have so far only been established with cryptophytes within the Teleaulax clade as prey (i.e. Teleaulax amphioxeia, T. acuta 
and Geminigera cryophila; Gustafson et al. 2000, Yih et al. 2004, Hansen \& Fenchel 2006, Park et al. 2007, P. J. Hansen et al. unpubl.). M. pulex has so far been reported to feed on the dinoflagellate Heterocapsa rotundata and the ciliate Metanophrys sp., and successful cultures have been established on both types of prey (Dolan \& Coats 1991, Jakobsen \& Strom 2004, Jakobsen et al. 2006). It has been shown to be a very inefficient grazer on the cryptophyte Rhodomonas salina or the dinoflagellate Protodinium simplex (= Gymnodinium simplex), mainly due to a very low successful capture rate. Also, it will not ingest artificial beads (Dolan \& Coats 1991, Carrias et al. 1996). A recent study has suggested that M. rubrum also ingests bacteria (Myung et al. 2006); however, the mechanism of capture of the smallsized bacteria is unknown at this time and it is currently unknown if $M$. rubrum can sustain growth on bacteria.

Detailed physiological studies have only been carried out on temperate strains and an Antarctic strain of Mesodinium rubrum (Yih et al. 2004, Johnson \& Stoecker 2005, Hansen \& Fenchel 2006, Park et al. 2007, Smith \& Hansen 2007). This species, which forms symbiosis with cryptophytes, is predominantly phototrophic and can only grow in the light. Maximum growth rates are obtained at very low prey concentrations (1000 prey cells ml $\mathrm{m}^{-1}$ ) and at very low food uptake rates ( 1 to $2 \%$ of total carbon uptake; Smith \& Hansen 2007). When subjected to sudden starvation, $M$. rubrum will perform 3 to 4 cell divisions and replicate its cryptophyte chloroplasts and, at least in some isolates, also its symbiont nucleus (Hansen \& Fenchel 2006, Johnson et al. 2007, Smith \& Hansen 2007). Thereafter, it is able to starve for up to a month depending on the incubation temperature. Very little is known about the physiology of the non-symbiontcontaining species, and their photosynthetic potential has never been studied (Jakobsen et al. 2006). However, prior to this study, we observed that M. pulex cells are often filled with autotrophic food even after the prey has been depleted, indicating possible active photosynthesis.

The aim of the present work was to study the prey selection and feeding physiology of a non-symbiontcontaining Mesodinium species. We chose M. pulex because it is a very common species around the world (Al-Rasheid 2001) and because it is the only species which at the moment can be held in laboratory culture. We hypothesized that: (1) M. pulex is an omnivorous feeder that relies on its ability to sense and successfully catch prey cells, and (2) M. pulex can carry out photosynthesis in the light and this carbon uptake in light will increase its growth rate or allow it to survive better when suddenly starved.

\section{MATERIALS AND METHODS}

Culture of organisms. Mesodinium pulex was provided by the culture collection of the Marine Biological Laboratory (Helsingør, Denmark). It had originally been isolated from water samples collected from a boat launch near Shannon Point Marine Center, Washington, USA, by H. H. Jakobsen (Jakobsen et al. 2006). Cultures of $M$. pulex were maintained on the dinoflagellate Heterocapsa rotundata unless otherwise stated. The organisms were grown at a temperature of $20 \pm$ $1{ }^{\circ} \mathrm{C}$ in enriched filtered $(0.22 \mu \mathrm{m}) \mathrm{f} / 20$ seawater medium (Guillard 1983) at a salinity of $30 \pm 1$ psu without silicate. Light was provided by cool-white fluorescent light at a $14 \mathrm{~h}$ light:10 h dark cycle with an illumination of ca. $100 \mu \mathrm{mol}$ photons $\mathrm{m}^{-2} \mathrm{~s}^{-1}$. Other prey items (cryptophytes, see Table 1) used in some experiments were grown in enriched filtered $\mathrm{h} / 20$ seawater media, which is basically the same as $\mathrm{f} / 20$, except that it also includes ammonium (modified from $\mathrm{h} / 2$ medium; Guillard 1975), otherwise the growth conditions were as stated above. All cultures were nonaxenic.

Cell volume. Cell length and width of Lugol's solution-preserved organisms were measured in a Sedgewick-Rafter chamber under an inverted microscope at 400× magnification. Suitable geometrical forms of organisms were used and the cell volumes were calculated according to Hillebrand et al. (1999). The following geometrical forms were used: a cone with hemisphere was used for Mesodinium pulex, Heterocapsa rotundata, Teleaulax sp. and T. amphioxeia, while a prolate spheroid was used for Guillardia theta, Hemiselmis rufescens and Hemiselmis tepida. The equivalent spherical diameter (ESD) was estimated by the equation: ESD = (biovolume/0.523) ${ }^{0.33}$. Carbon contents of $M$. pulex and the prey organisms were estimated with the carbon conversion factor: pg C cell ${ }^{-1}=0.216 \times$ volume $^{0.939}$ and pg $\mathrm{C}$ cell $^{-1}=0.760 \times$ volume $^{0.819}$, respectively (Menden-Deuer \& Lessard 2000).

Feeding and growth of Mesodinium pulex fed different prey items. This experiment was designed to test whether $M$. pulex was able to feed and grow on a variety of cryptophytes and a dinoflagellate (Table 1). For comparison we ran control experiments with $M$. pulex in monocultures (thus exposed to starvation). Preliminary experiments had shown that some of the cryptophytes cannot grow on the f/20 medium, because they cannot use nitrate as an inorganic N-source. We therefore switched to the $\mathrm{h} / 20$ medium. Prior to the initiation of the experiments, $M$. pulex had been grown on Heterocapsa rotundata and allowed to deplete $H$. rotundata as prey (= residual prey concentrations less than ca. 5 cells $\mathrm{ml}^{-1}$ ). 
Table 1. Algae used in the experiments, their cell volumes $( \pm \mathrm{SE})$, estimated spherical diameters ( $E S D ; n=20$ ), and culture identification

\begin{tabular}{|lccc|}
\hline $\begin{array}{l}\text { Species } \\
\text { (taxa) }\end{array}$ & $\begin{array}{c}\text { Cell volume } \\
\left(\mu^{3}\right)\end{array}$ & $\begin{array}{c}\text { ESD } \\
(\mu \mathrm{m})\end{array}$ & $\begin{array}{c}\text { Culture collection } \\
\text { ID number }\end{array}$ \\
\hline $\begin{array}{l}\text { Heterocapsa rotundata } \\
\text { (Dinophyceae) }\end{array}$ & $142 \pm 13$ & 6.3 & SCCAP-K0441 \\
$\begin{array}{c}\text { Teleaulax amphioxeia } \\
\text { (Cryptophyceae) }\end{array}$ & $127 \pm 9.5$ & 6.1 & SCCAP \\
$\begin{array}{c}\text { Teleaulax sp. } \\
\text { (Cryptophyceae) } \\
\begin{array}{c}\text { Guillardia theta } \\
\text { (Cryptophyceae) }\end{array}\end{array}$ & $105 \pm 2.9$ & 5.8 & MBL-1 \\
$\begin{array}{c}\text { Hemiselmis rufescens } \\
\text { (Cryptophyceae) }\end{array}$ & $72 \pm 4.3$ & 5.0 & CCMP-440 \\
$\begin{array}{c}\text { Hemiselmis tepida } \\
\text { (Cryptophyceae) }\end{array}$ & $58 \pm 4.8$ & 4.7 & CCMP-442 \\
\hline
\end{tabular}

This experiment was carried out at an irradiance of $100 \mu \mathrm{mol}$ photons $\mathrm{m}^{-2} \mathrm{~s}^{-1}$.

Preliminarily, the initial predator-prey concentration ratio was set at ca. 25:1250 cells $\mathrm{ml}^{-1}$, to ensure sufficient prey in mixed culture during the experimental period (4 d). However, it turned out that Mesodinium pulex could not control the cryptophyte prey populations. We therefore used an initial predatorprey concentration ratio of ca. 200:1000 cells ml ${ }^{-1}$ (1:5 ratio) on Day 0. Monocultures of cryptophytes were initiated at a concentration of ca. 1000 cells ml-1 Subsamples (5 to $10 \mathrm{ml}$ ) were withdrawn on Days 0, 2 and 4 from triplicates of $65 \mathrm{ml}$ tissue culture bottles and cells were counted. After subsampling on Day 2, all experimental bottles were refilled to capacity with fresh filtered $\mathrm{h} / 20$ medium. In cases where prey populations had been almost depleted during the first $2 \mathrm{~d}$ of the experiment, additional prey was added to the experimental bottles. Only the cultures in which $M$. pulex displayed growth between Days 2 and 4 were allowed to continue to Day 6. During the experimental period, a Sentron ${ }^{\circledR} \mathrm{pH}$ meter (model 2001) equipped with a Red-Line probe (detection limit of $0.01 \mathrm{pH}$ units) was used to measure $\mathrm{pH}$ in all experimental bottles. The $\mathrm{pH}$ meter probe was calibrated with Sentron buffers of $\mathrm{pH} 7$ and 10.

The growth/mortality rate of Mesodinium pulex $\left(\mu_{y}\right)$ and prey cells $\left(\mu_{x}\right)$ was calculated assuming exponential growth/mortality:

$$
\mu_{y, X}\left(\mathrm{~d}^{-1}\right)=\frac{\left(\ln N_{1}-\ln N_{0}\right)}{t}
$$

where $N_{0}$ and $N_{1}$ are cell number at the start $\left(t_{0}\right)$ and end $\left(t_{1}\right)$ of each incubation experiment, respectively, and $t$ is the time interval between samplings (d).

The ingestion rate $U$ is the per capita ingestion rate, which is dependent on prey $(x)$. This was estimated using the following 2 equations:

$$
\begin{gathered}
\frac{\mathrm{d} x}{\mathrm{~d} t}=\mu_{x}-U_{y} \\
\frac{\mathrm{d} y}{\mathrm{~d} t}=\mu_{y} y
\end{gathered}
$$

Ingestion rate of Mesodinium pulex was calculated assuming that predator $(y)$ and prey $(x)$ grow exponentially with rate constants of $\mu_{y}$ and $\mu_{x}$, respectively. The decrease in prey due to grazing is $U_{y}$. This ingestion rate was calculated using software as described in Jakobsen \& Hansen (1997).

Growth and ingestion rates of Mesodinium pulex were fitted to the Michaelis-Menten equation, using the software SigmaPlot 10 (Systat Software):

$$
\mu\left(\mathrm{d}^{-1}\right)=\frac{\mu_{\max }\left(x-x_{0}\right)}{K_{\mu m}+\left(x-x_{0}\right)}
$$

where $\mu_{\max }$ is the maximal growth rate of $M$. pulex, $x$ is the actual prey concentration, $x_{0}$ is the threshold prey concentration for growth (where $\mu_{y}=0$ ) and $K_{\mu m}$ is the prey concentration sustaining $1 / 2 \mu_{\max }$ and:

$$
U\left(\mathrm{~d}^{-1}\right)=\frac{U_{\max }(x)}{K_{U m}+(x)}
$$

where $U_{\max }$ is the maximal ingestion rate per $M$. pulex (prey cells predator ${ }^{-1} \mathrm{~d}^{-1}$ ), $x$ is the prey concentration (cells $\mathrm{ml}^{-1}$ ) and $K_{U m}$ is the prey concentration sustaining $1 / 2 U_{\text {max }}$.

For statistical analysis, $t$-test analyses were used to test for differences found in rates between dark and light treatments. $t$-test and ANOVA were used to compare means (ingestion rate and growth rate) between each prey to zero and between each other, respectively.

Photosynthetic performance of Mesodinium pulex and the prey Heterocapsa rotundata. The photosynthetic performance of $M$. pulex cultures when fed the dinoflagellate $H$. rotundata was measured at an irradiance of $100 \mu \mathrm{mol}$ photons $\mathrm{m}^{-2} \mathrm{~s}^{-1}$. The photosynthetic performance was measured both in well-fed M. pulex cultures and in cultures which had almost depleted their prey. In the first case, M. pulex cells were separated from prey by individually picking the ciliates with a drawn Pasteur pipette and transferring them to $0.2 \mu \mathrm{m}$ filtered growth medium. This was repeated 3 times to exclude all $H$. rotundata. In the second case, $M$. pulex cultures were allowed to almost deplete their prey, before bulk measurements of the mixed cultures were carried out (see Table 2). Subsamples were taken for enumeration of prey and M. pulex cells. This allowed for subtraction of the contribution of $H$. rotundata to the total photosynthe- 
sis and thus an estimation of the photosynthetic performance due to $M$. pulex cells.

Photosynthetic rates were measured by a modification of the 'single cell method' (Stoecker et al. 1988, Skovgaard et al. 2000). A $\mathrm{NaH}^{14} \mathrm{CO}_{3}{ }^{-}$stock solution (specific activity $100 \mu \mathrm{Ci} \mathrm{ml}^{-1}$ ) was then added to each vial, containing $2 \mathrm{ml}$ cell suspension, resulting in a specific activity of $\sim 1.0 \mu \mathrm{Ci} \mathrm{ml}{ }^{-1}$. The $2 \mathrm{ml}$ cell suspension contained either 20 or 40 ciliates when the cells were picked individually, while it contained in the range of 400 to 1300 cells when the photosynthetic performance was carried out on the mixed cultures (see Table 2). The vials were incubated on a glass shelf with light coming from beneath for $2 \mathrm{~h}$. All measurements were carried out in triplicate. The vials were always accompanied by parallel dark vials, which were treated similarly, except that they were wrapped in aluminum foil during incubation.

After incubation, the specific activity of the medium was measured by transferring $100 \mu \mathrm{l}$ from each vial to new vials containing $200 \mu \mathrm{l}$ phenylethylamine. The remaining suspension received $2.0 \mathrm{ml}$ of $10 \%$ acetic acid in methanol to remove all inorganic $\mathrm{C}$. The vials were dried overnight at $60^{\circ} \mathrm{C}$ and the residue was then re-dissolved in $1.5 \mathrm{ml}$ distilled water. Finally, $10 \mathrm{ml}$ of Packard Insta-Gel Plus scintillation flour were added to all vials (including those for specific activity) and activity was measured using a Packard 1500 TriCarb liquid scintillation counter. Calculations of photosynthetic rates were based on Parsons et al. (1984). Total dissolved inorganic carbon content was measured with a 225-Mk3 infrared gas analyzer (Analytic Development).

Functional and numerical response in the light and in the dark. These experiments were designed to test the effect of light on growth and ingestion rates of Mesodinium pulex. Heterocapsa rotundata was selected as prey based on the prey selection experiments. Experiments were initiated by mixing exponentially growing cultures of $M$. pulex and $H$. rotundata. Cultures of $H$. rotundata were also run as monocultures, thereby allowing the calculation of ingestion rates. All experiments were carried out in triplicate in $65 \mathrm{ml}$ tissue culture bottles filled to capacity. The experiments were carried out in darkness (culture bottles were wrapped in aluminum foil), and at an irradiance of $100 \mu \mathrm{mol}$ photons $\mathrm{m}^{-2} \mathrm{~s}^{-1}$. Irradiance was measured using a LI-COR, LI-1000 radiation sensor equipped with a spherical probe. The initial prey concentrations during these experiments were approximately 450 to 18200 cells ml $\mathrm{m}^{-1}$ and a prey:predator cell concentration ratio of $>10$ (based on preliminary data). The initial $2 \mathrm{~d}$ of the incubation served as acclimation to light and prey concentration. Subsamples (5 to $10 \mathrm{ml}$ ) were taken for cell counts every 1 to $2 \mathrm{~d}$, depending on growth rates, during the experimental period ( 3 to $6 \mathrm{~d}$ ) at a fixed time of day to eliminate potential diurnal variations in ingestion and growth rates of $M$. pulex. Subsamples were fixed in Lugol's solution (final concentration 1\%) and counted on an inverted microscope at 100× magnification. A Sedgewick-Rafter chamber was used for counting

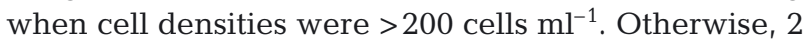
$\mathrm{ml}$ or sometimes $25 \mathrm{ml}$ sedimentation chambers were used in cases where cell numbers were lower. To avoid pH affecting the growth of $H$. rotundata and $M$. pulex, $\mathrm{pH}$ was monitored during all the experiments with high prey concentrations (>8000 cells $\mathrm{ml}^{-1}$ ), directly in bottles. Subsequently, the experimental bottles were refilled to capacity with fresh filtered f/20 media. To keep prey concentrations stable and to avoid effects of $\mathrm{pH}$, dilution of the experimental bottles and/or addition of prey cells was often required.

Responses of Mesodinium pulex to starvation in the light and in the dark. This experiment was designed to examine whether or not light affects growth/survival responses of $M$. pulex when starved. This experiment was conducted in darkness, and at 100 and $50 \mu \mathrm{mol}$ photons $\mathrm{m}^{-2} \mathrm{~s}^{-1}$ for 18 to $21 \mathrm{~d}$. Initial predator-prey concentration ratio was ca. 200:2800 cells ml-1 $\mathrm{mono}^{-1}$ cultures of Heterocapsa rotundata were also run parallel with all mixed cultures. The experiments were adapted to each irradiance level for $2 \mathrm{~d}$ (Days 0 to 2). Subsamples (5 to $10 \mathrm{ml}$ ) were collected on Days 2, 3 and 4 , and thereafter every $2 \mathrm{~d}$ until the termination of each experiment, and the experimental bottles were filled to capacity with fresh filtered f/20 media. The mortality rate was calculated in the same way as growth (see previous section). For comparison between light treatments, $t$-test analyses were used to test for differences between means. Mean values were averaged using only data after Day 4 (= prey concentration below detection limit).

\section{RESULTS}

\section{Feeding and growth of Mesodinium pulex fed different prey items}

The culture of Mesodinium pulex subjected to starvation decreased in cell concentration throughout the duration of the experiments and estimated mortality rates were in the range of 0.85 to $1.07 \mathrm{~d}^{-1}$ after Day 2 (Figs. 1A \& 2A). In the experiment where $M$. pulex was fed Heterocapsa rotundata at an initial prey concentration of 1000 cells $\mathrm{ml}^{-1}$, the ciliate almost depleted the prey during the first $2 \mathrm{~d}$ of the incubation and negative growth of the ciliate was observed $\left(-0.02 \mathrm{~d}^{-1}\right)$ (Fig. 1B). Additional prey was therefore added on Day 2, thereby 

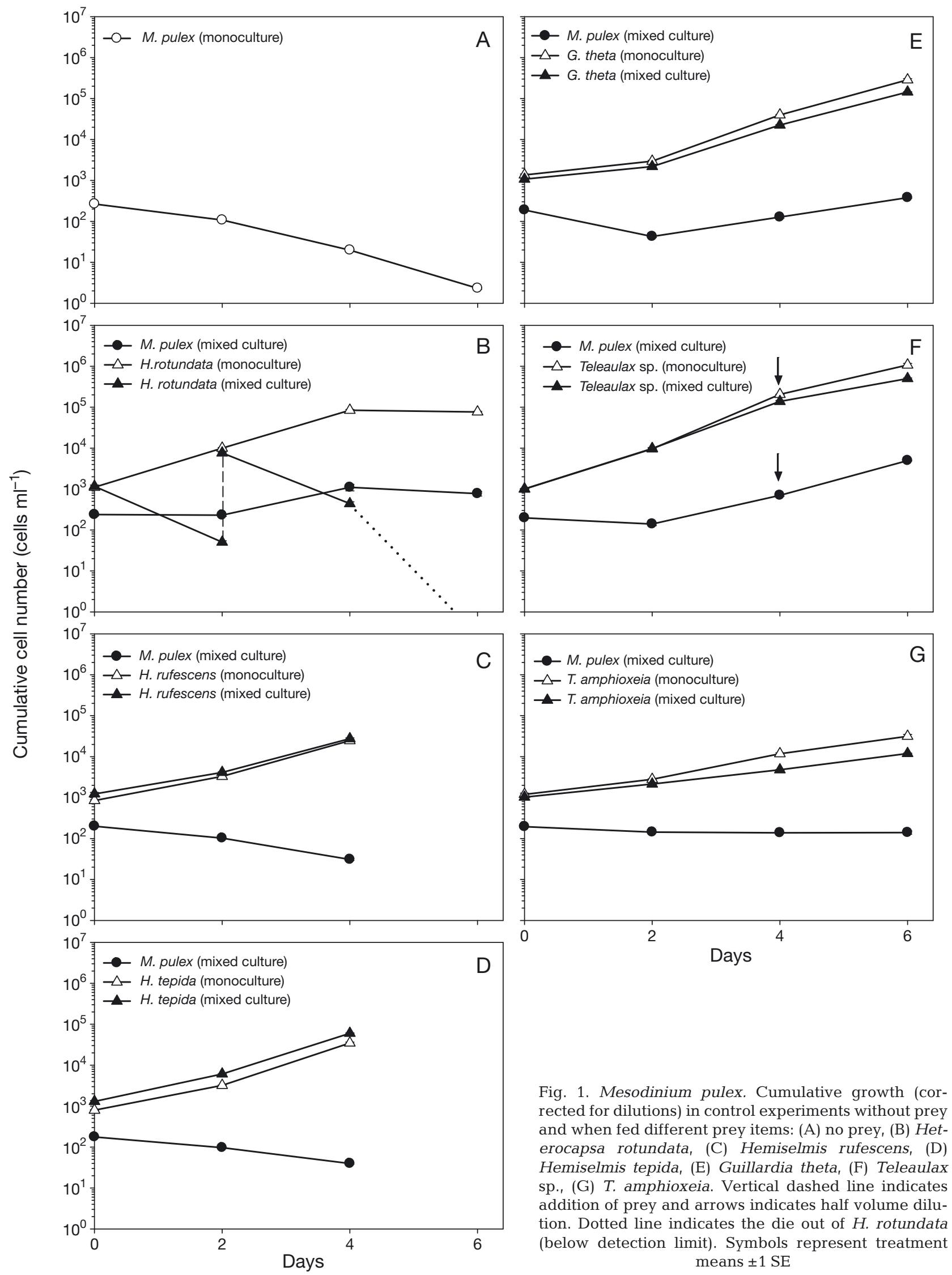

Fig. 1. Mesodinium pulex. Cumulative growth (corrected for dilutions) in control experiments without prey and when fed different prey items: (A) no prey, (B) Heterocapsa rotundata, (C) Hemiselmis rufescens, (D) Hemiselmis tepida, (E) Guillardia theta, (F) Teleaulax sp., (G) T. amphioxeia. Vertical dashed line indicates addition of prey and arrows indicates half volume dilution. Dotted line indicates the die out of $H$. rotundata (below detection limit). Symbols represent treatment means $\pm 1 \mathrm{SE}$ 

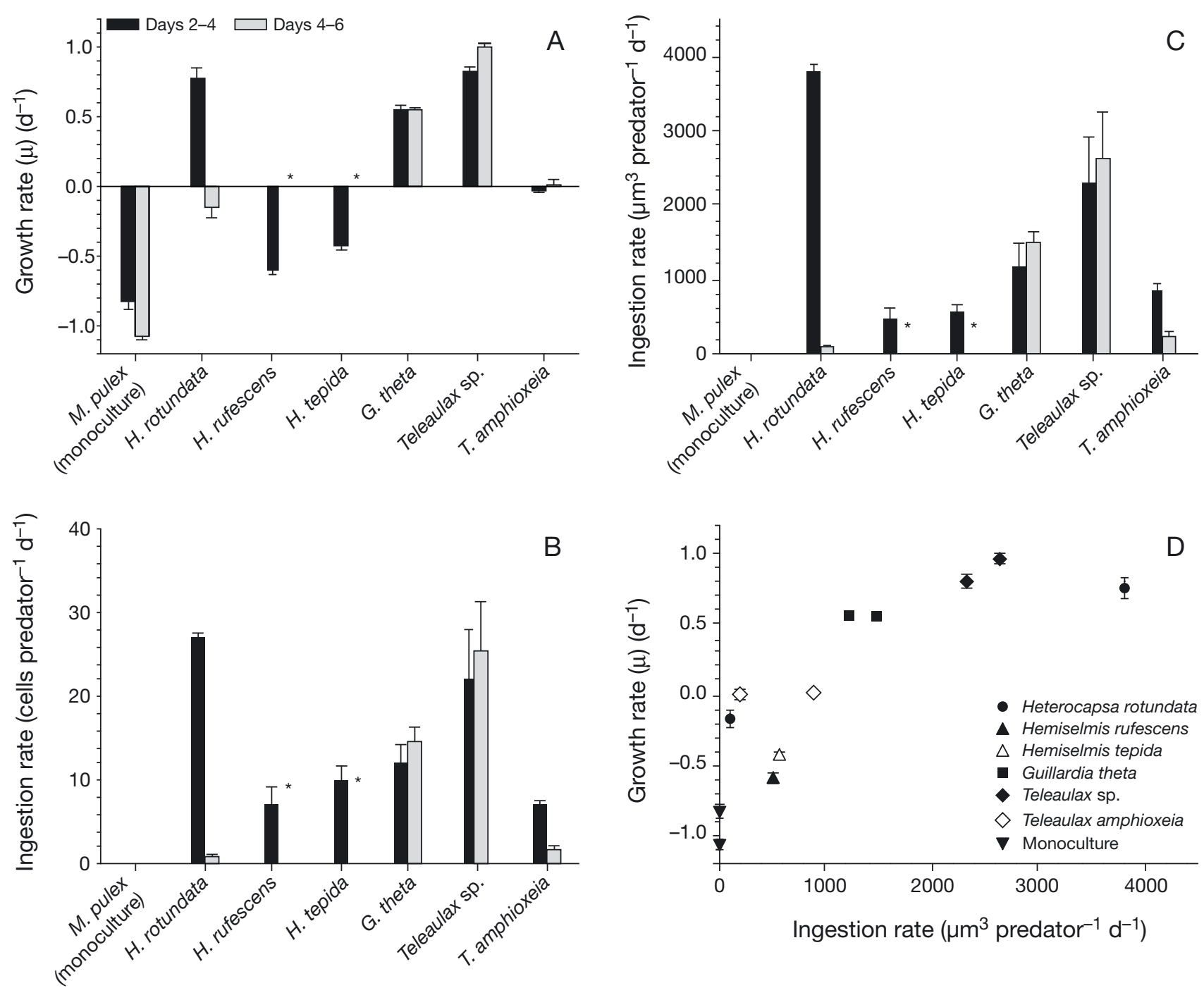

Fig. 2. Mesodinium pulex. (A) Growth rate when fed different prey items. (B) Ingestion rate. (C) Ingestion rate in terms of biovolume of M. pulex. (D) Growth rate as a function of ingested prey biovolume. Asterisk indicates that the experiment was ended on Day 4. Bars and symbols represent treatment means \pm 1 SE. See Fig. 1 legend for species names

increasing the $H$. rotundata cell concentration to 10000 cells $\mathrm{ml}^{-1}$. On Day 4, the prey populations had been considerably reduced, and M. pulex had grown at an average rate of $0.78 \mathrm{~d}^{-1}$ during this period (Fig. 2A). Additional prey was not added on Day 4, which led to a depletion of prey on Day 6, and a decrease in $M$. pulex concentration.

The response of Mesodinium pulex to the cryptophytes was quite different than to that to Heterocapsa rotundata. M. pulex ingested all of the offered species; however, it was unable to control the growth of any of them (Figs. 1 \& 2). Significantly higher ingestion rates were obtained with Teleaulax sp. as prey ( 22 to 25 cells predator $\left.{ }^{-1} \mathrm{~d}^{-1}\right)$, compared to the other prey species $(2$ to 15 cells predator ${ }^{-1} \mathrm{~d}^{-1}$; Student's $t$-test $\mathrm{p}<0.05$;
Fig. 2B). Taking the different cell volumes of the individual prey (Table 1) allowed ingested biovolume in each case to be calculated (Fig. 2C). From this, it is evident that the difference in growth rates on the different prey is reflected in different levels of ingestion rates (in terms of biovolume; Fig. 2C,D).

The highest growth rate of Mesodinium pulex in this experiment was obtained on Teleaulax sp. (0.8 to 1.0 $\mathrm{d}^{-1}$ ). However, this growth rate was obtained at a much higher cell concentration than when $M$. pulex was fed Heterocapsa rotundata (Figs. 1 \& 2). M. pulex also grew well when fed Guillardia theta, although growth rates were significantly lower $\left(0.5 \mathrm{~d}^{-1}\right.$; Student's $t$-test $)$ than when fed $H$. rotundata (Student's $t$-test, $\mathrm{p}<0.05$ ). When fed T. amphioxeia, Hemiselmis rufescens or 
Hemiselmis tepida, M. pulex either maintained its population (on T. amphioxeia) or died out during the incubation, even though cell concentrations became high (H. rufescens and H. tepida). Overall, it seems likely that $M$. pulex needs to ingest a biovolume of $>500$ to $1000 \mathrm{\mu m}^{3} \mathrm{~d}^{-1}$ to support growth when fed cryptophytes (Fig. 2D).

The $\mathrm{pH}$ of the medium was monitored in both monocultures and in the mixed cultures throughout the duration of the experiments (Fig. 3). In the mixed cultures, it remained below $\mathrm{pH}$ 8.1, except for the mixed culture with Teleaulax sp. as prey. Here it increased to $\mathrm{pH} 8.6$ at the end of the experiment. In the algal monoculture, $\mathrm{pH}$ increased to reach high values in the cases of Teleaulax sp. and Heterocapsa rotundata ( $\mathrm{pH} 9$ ). This coincides with the entry into stationary growth observed in the monocultures of these species between Days 4 and 6 (Fig. 1B,F).

\section{Photosynthetic performance of Mesodinium pulex and the prey Heterocapsa rotundata}

The photosynthetic performance of Mesodinium pulex was $2.3 \pm 0.86 \mathrm{pg} \mathrm{C}$ cell $^{-1} \mathrm{~h}^{-1}$ (average $\pm \mathrm{SE}$ ) when fed the dinoflagellate Heterocapsa rotundata in excess at an irradiance of $100 \mu \mathrm{mol}$ photons $\mathrm{m}^{-2} \mathrm{~s}^{-1}$ (Table 2). This is equivalent to a daily rate of ca. $32 \mathrm{pg}$ C cell ${ }^{-1}$ (14 h light:10 h dark cycle). In M. pulex cultures that had just about depleted the prey in mixed cultures, the photosynthetic performance was much lower, $0.37 \pm 0.08 \mathrm{pg} \mathrm{C}$ cell $^{-1} \mathrm{~h}^{-1}$ (average $\pm \mathrm{SE}$ ) (Table 2). This is equivalent to ca. $5.2 \mathrm{pg} \mathrm{C}$ cell $^{-1} \mathrm{~d}^{-1}$. For comparison, the photosynthetic performance of $H$. rotundata cells in monocultures was $3.76 \pm 0.18 \mathrm{pg}$ $\mathrm{C}$ cell $^{-1} \mathrm{~h}^{-1}$ or $52 \pm 2.7 \mathrm{pg} \mathrm{C}$ cell $^{-1} \mathrm{~d}^{-1}$ (average $\pm \mathrm{SE}$, $\mathrm{n}=21$ ).

\section{Functional and numerical responses in the dark and in the light}

The functional response of Mesodinium pulex fed Heterocapsa rotundata was investigated in the light (100 $\mu$ mol photons $\mathrm{m}^{-2} \mathrm{~s}^{-1}$ ) and in the dark (Fig. 4A). Maximum ingestion rate was 49 cells predator ${ }^{-1} \mathrm{~d}^{-1}$ in the light, while in the dark it was considerably lower, 27 cells predator ${ }^{-1} \mathrm{~d}^{-1}$ ( $t$-test, $\mathrm{p}<0.01)$. Half saturation constants were 1210 and 1580 cells $\mathrm{ml}^{-1}$ for the light and dark treatments, respectively. Ingestion rates of $\sim 35$ and 15 cells predator ${ }^{-1} \mathrm{~d}^{-1}$ were sufficient to maintain maximum growth
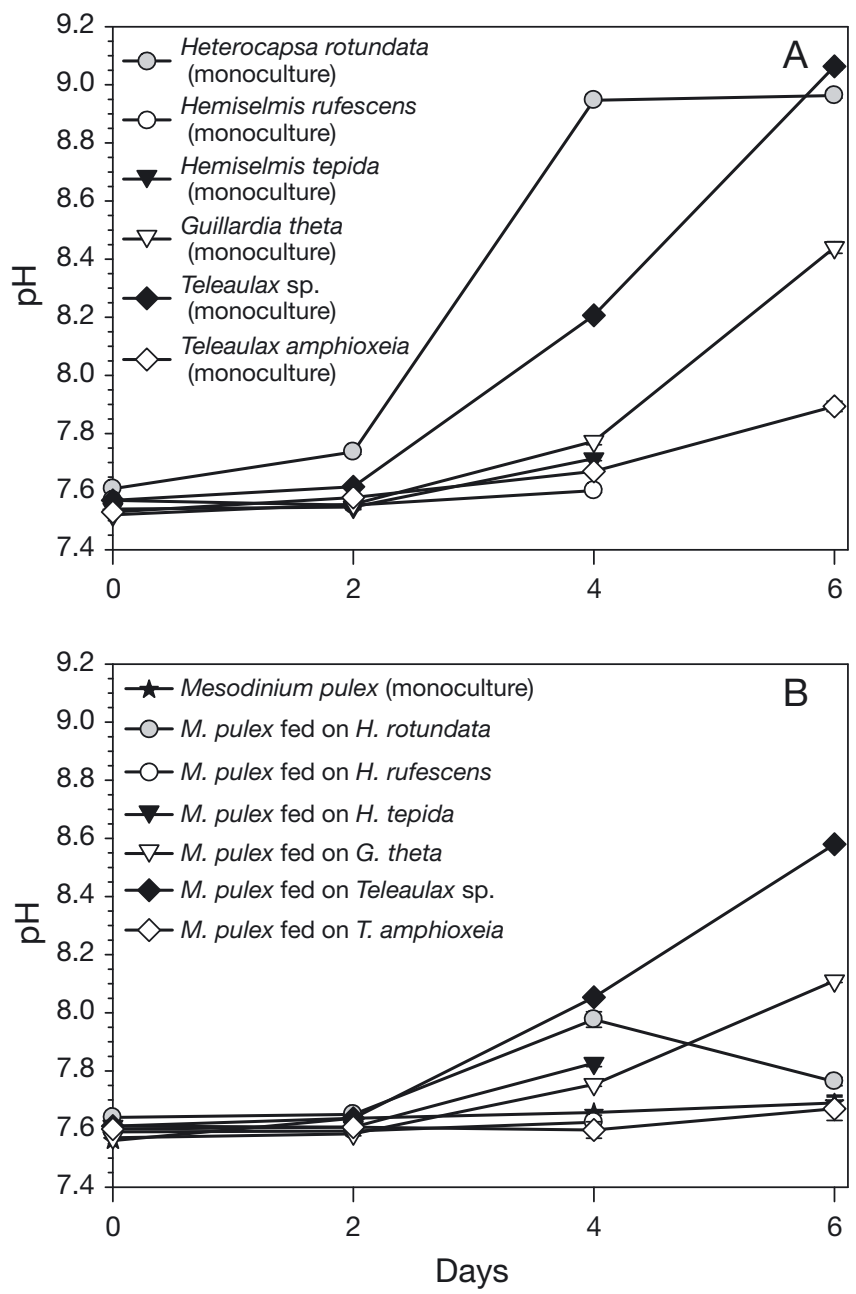

Fig. 3. $\mathrm{pH}$ dynamics in (A) monocultures of the prey items and (B) monocultures of Mesodinium pulex and mixed cultures of prey and predator. Symbols represent treatment means \pm 1 SE. See Fig. 1 legend for species names

rate of $M$. pulex in the light and in the dark, respectively (Fig. 4A).

The growth rate of Mesodinium pulex fed Heterocapsa rotundata followed Michaelis-Menten kinetics both in the light and in the dark (Fig. 4B). In the light, the growth rate of $M$. pulex reached a maxi-
Table 2. Mesodinium pulex fed Heterocapsa rotundata. Photosynthetic performance of well-fed and starved M. pulex cells. Numbers are average $\pm 1 \mathrm{SE}$, $\mathrm{n}=$ number of replicates

\begin{tabular}{|lcccc|}
\hline $\begin{array}{l}\text { Physiological } \\
\text { state }\end{array}$ & $\begin{array}{c}\text { Range in } \\
\text { ciliate conc. } \\
\left(\text { cells ml }{ }^{-1}\right)\end{array}$ & $\begin{array}{c}\text { Range in } \\
\text { prey conc. } \\
\left(\text { cells ml }^{-1}\right)\end{array}$ & $\begin{array}{c}\text { Photosynthetic } \\
\text { rate } \\
\left(\mathrm{pg} \mathrm{C} \mathrm{cell}^{-1} \mathrm{~h}^{-1}\right)\end{array}$ & $\mathrm{n}$ \\
\hline $\begin{array}{l}\text { Starving cells } \\
\text { Well-fed cells }\end{array}$ & $210-645$ & $4-83$ & $0.37 \pm 0.08$ & 21 \\
\hline
\end{tabular}



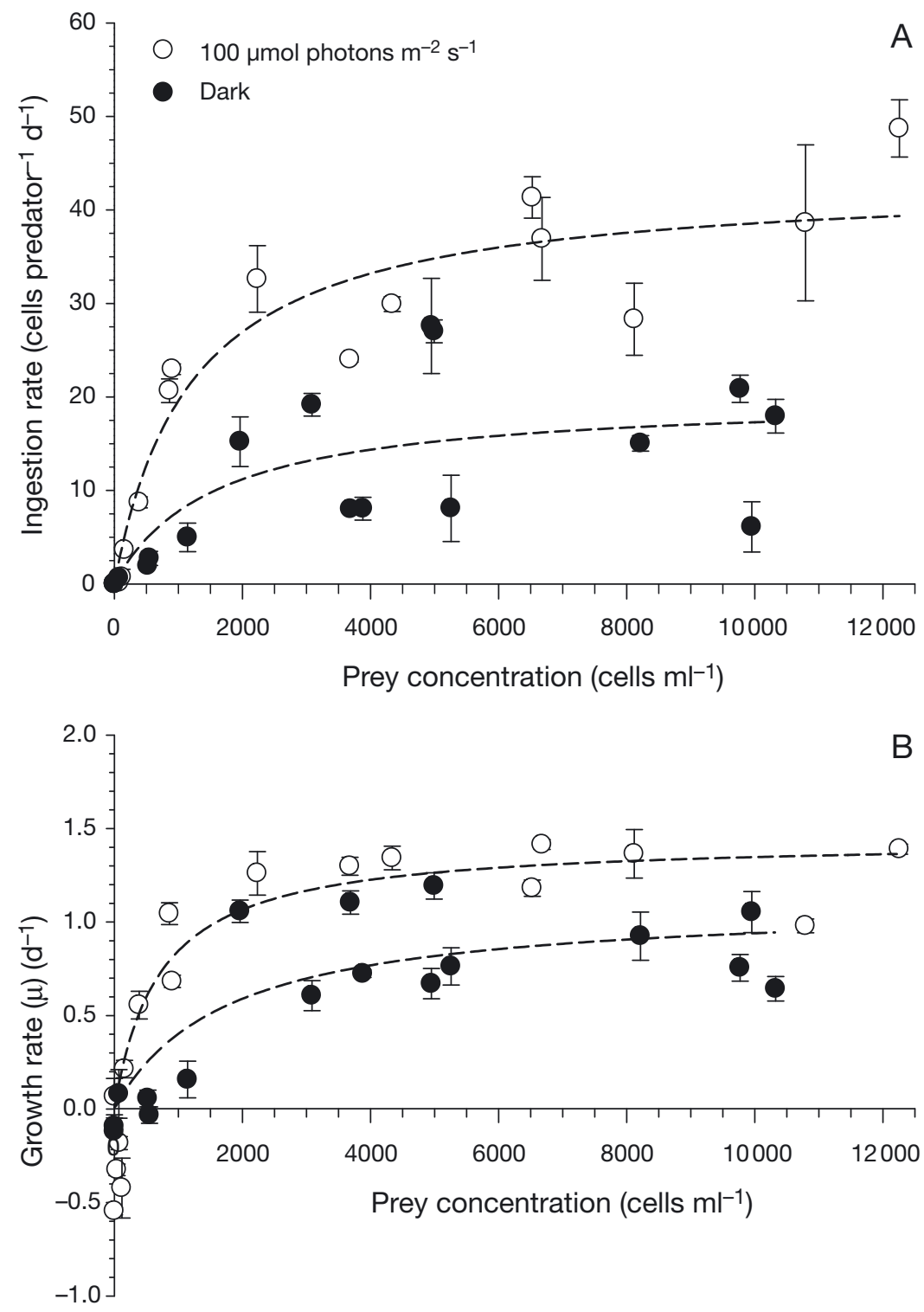

Fig. 4. Mesodinium pulex fed Heterocapsa rotundata. Functional and numerical responses. (A) Ingestion and (B) growth rate of $M$. pulex in the dark and at an irradiance of $100 \mu \mathrm{mol}$ photons $\mathrm{m}^{-2} \mathrm{~s}^{-1}$ as a function of prey concentration $\left(C_{\mathrm{p}}\right)$. Symbols represent treatment means $\pm 1 \mathrm{SE}$. The curves were fitted to MichaelisMenten kinetics. $\mu=1.44 \times\left(C_{p}-40\right) /\left(707+\left(C_{p}-40\right)\right)$ for the light and $\mu=1.10 \times$ $\left(C_{\mathrm{p}}-10\right) /\left(1745+\left(C_{\mathrm{p}}-10\right)\right)$ for the dark treatments, respectively

\section{Response of Mesodinium pulex to starvation in the dark and at 2 light levels}

The effect of starvation on survival and cell volume of Mesodinium pulex when exposed to irradiances of 100 and $50 \mu \mathrm{mol}$ photons $\mathrm{m}^{-2} \mathrm{~s}^{-1}$ and to darkness was studied (Fig. 5). During the acclimation period (Days 0 to 2), prey concentrations were high in all cases, leading to initial high growth rates of $M$. pulex (Fig. 5D). Prey was depleted on Days 3 and 4 in the light and in the dark, respectively, and $M$. pulex subjected to sudden starvation. Initial growth rates were $0.99,0.95$ and $0.71 \mathrm{~d}^{-1}$ (Days 0 to 2 ) for the light treatments (100 and $50 \mu \mathrm{mol}$ photons $\mathrm{m}^{-2}$ $\mathrm{s}^{-1}$ ) and the dark, respectively. These initial growth rates changed to mortality rates of $0.55,0.62$ and $0.09 \mathrm{~d}^{-1}$ for the light treatments (100 and $50 \mu \mathrm{mol}$ photons $\mathrm{m}^{-2} \mathrm{~s}^{-1}$ ) and the dark, respectively, during Days 4 to 6 (Fig. 5D). After Day 6, the mortality rates stayed fairly constant over the next 10 to $14 \mathrm{~d}$, maybe with the exception of a slightly increased mortality rate from 0.46 to $0.73 \mathrm{~d}^{-1}$ during Days 12 to 16 in the light treatments. From Day 6, the mortality rates in the light treatments were significantly higher than in the dark ( $t$-test, $\mathrm{p}<0.05)$. No difference in the mortality rates between high light and medium light was apparent in the same period ( $t$-test, $\mathrm{p}>0.05$ ).

The cell volumes of Mesodinium pulex decreased slightly from Day 2 to Day 6 of the starvation experiment in all treatments (Fig. 5E). After Day 6, the cell volumes were constant. The observed changes were not significantly different among treatments ( $t$-test, p > 0.05).

Growth/survival experiments were also carried out on monocultures of Heterocapsa rotundata in the 2 light levels and dark to follow the fate of the prey organisms in the 3 treatments (Fig. 5A-C). In the high and medium light treatments, $H$. rotundata grew at a rate of 1.11 and $0.90 \mathrm{~d}^{-1}$, respectively, for the first $6 \mathrm{~d}$ of the incubation. In the dark treatment, $H$. rotundata maintained its cell concentration for the first $4 \mathrm{~d}$ of the incubation. However, on Day 6, no cells were left (detection level 5 cells $\mathrm{ml}^{-1}$ ). in the light. 

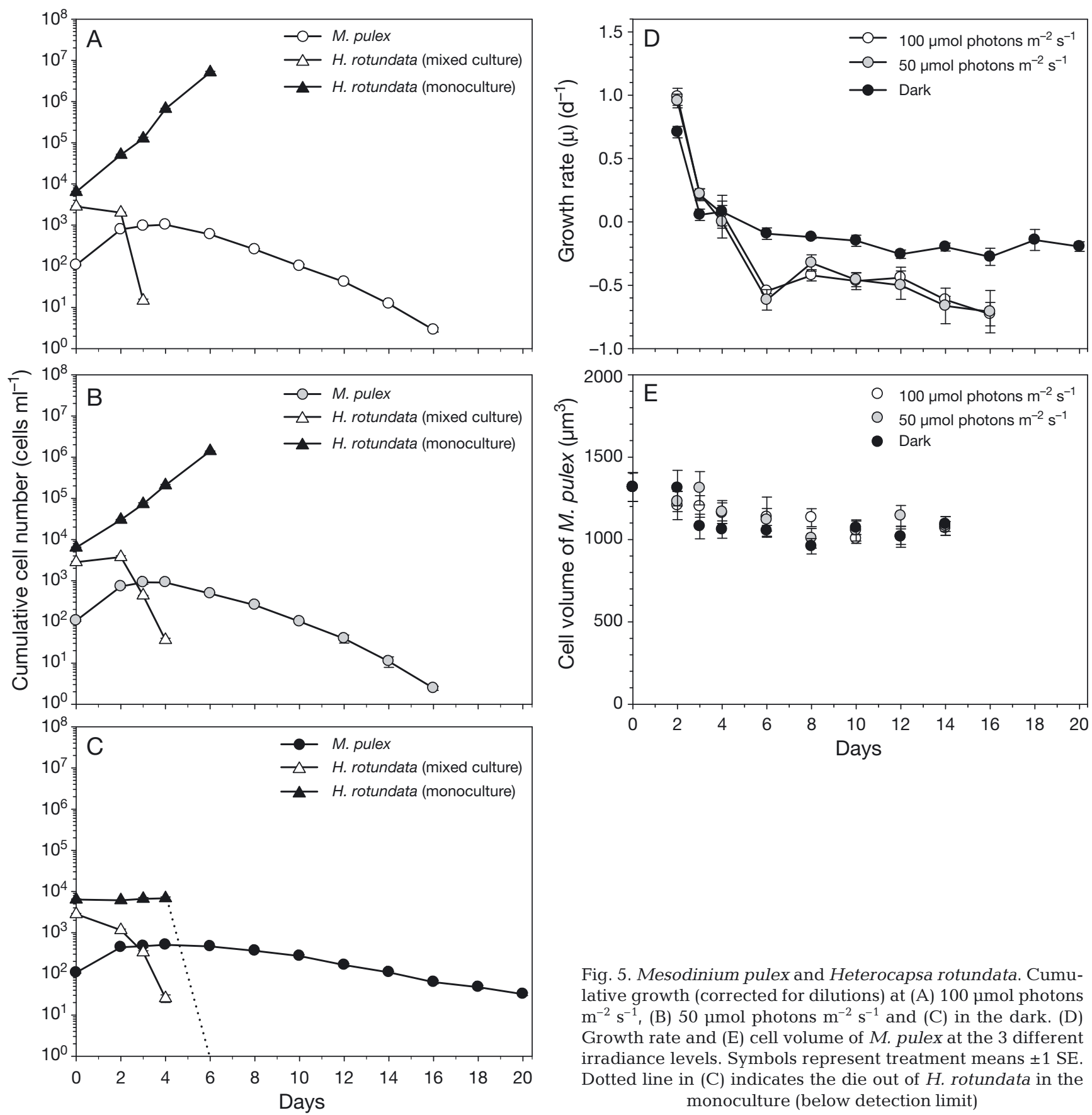

Fig. 5. Mesodinium pulex and Heterocapsa rotundata. Cumulative growth (corrected for dilutions) at (A) $100 \mu \mathrm{mol}$ photons $\mathrm{m}^{-2} \mathrm{~s}^{-1}$, (B) $50 \mu \mathrm{mol}$ photons $\mathrm{m}^{-2} \mathrm{~s}^{-1}$ and (C) in the dark. (D) Growth rate and (E) cell volume of $M$. pulex at the 3 different irradiance levels. Symbols represent treatment means $\pm 1 \mathrm{SE}$. Dotted line in $(\mathrm{C})$ indicates the die out of $H$. rotundata in the monoculture (below detection limit)

\section{DISCUSSION}

\section{Prey selection in Mesodinium pulex}

All Mesodinium species are phagotrophic and they seem to rely on motile prey for food (e.g. Dolan \& Coats 1991, Gustafson et al. 2000, Jakobsen et al. 2006). Prey capture in $M$. pulex has been studied in some detail (see Jakobsen et al. 2006). The motile prey is detected by a band of equatorial cirri encircling the cell, which sense hydrodynamic disturbances of the medium made by the swimming prey. Upon detection, M. pulex immobilizes the prey cell using the oral tentacles, which have extrusomes attached to each tentacle tip (Lindholm et al. 1988, Dolan \& Coats 1991, Tamar 1992, Jakobsen et al. 2006). The prey is then transported to the mouth by retraction of the tentacles (Jakobsen et al. 2006). 
In our study, Mesodinium pulex successfully ingested all the offered prey organisms, which were in the size range of 4.7 to $6.3 \mu \mathrm{m}$ (ESD). However, the ingestion rates varied in terms of both cells $\mathrm{h}^{-1}$ and biovolume $\mathrm{h}^{-1}$, allowing the ciliate to grow only when fed 2 out of the 5 different prey species offered. Previously, it has been shown that $M$. pulex cannot ingest algae like the haptophyte Phaeocystis globosa (4 $\mu \mathrm{m}$, single cells) or the cryptophyte Rhodomonas salina (ESD $7 \mu \mathrm{m}$ ) (Tang et al. 2001, Jakobsen et al. 2006). Also, quite low ingestion rates were obtained with the dinoflagellate Protodinium simplex (ESD $9 \mu \mathrm{M}$ ) as prey. This raises the question of what causes this differentiated ingestion rate of quite similarly sized prey cells.

Jakobsen et al. (2006) showed that fast-swimming prey like the dinoflagellate Protodinium simplex will make a high hydromechanical signal in the water that disguises it as a predator and the ciliate performs jumps upon encountering it in the same way as it does when escaping an approaching predator. None of the cryptophytes studied in the present investigation were particularly fast-swimming cells, so that explanation can be ruled out. However, since Mesodinium pulex feeds rheotactically on motile prey, swimming prey cells need to generate a sufficient deformation rate to trigger an attack. Thus, slow swimming among prey cells may be a strategy aimed at reducing detection. This leaves us with 2 possible mechanisms that can account for the low capture success of $M$. pulex on the cryptophytes. Either the ciliate is unable to physically capture the prey cells or cells are able, to a large extent, to evade being caught by jumping away from the ciliate or by reducing their deformation rate due to slow swimming.

Physical capture of prey cells by Mesodinium pulex involves 3 overall steps: prey immobilization using the extrusomes, followed by adhesion of the prey to the tentacle tips, and finally ingestion of the prey (Jakobsen et al. 2006). At each of the capture steps, there is a chance that $M$. pulex will fail to ingest the prey. Jakobsen et al. (2006) demonstrated that M. pulex paralyzed the cryptophyte Rhodomonas salina less efficiently than it did the dinoflagellate Heterocapsa rotundata, indicating that the initial attack is an important step in the capture success of $M$. pulex. However, attaching prey to the tentacles may involve a complex and often highly specific recognition process between prey surface lectins and glycoprotein binding sites on the predator that acts as a prey discriminating component in itself, as has been shown for other protists (Sakaguchi et al. 2001, Wootton et al. 2007). Our visual investigation in the inverted microscope did not suggest that the cryptophytes we offered to M. pulex could escape by jumping away from the ciliate upon attack. Hence, the low capture success is most likely a product of both the inability of the extrusomes to properly attack the prey and an inefficient predator-prey match of binding glycoproteins and prey lectins.

If this explanation is true, why is the low capture success not compensated for by high concentrations of prey cells? Even though cryptophyte concentrations were very high in some cases, ingestion rates were still low. The reasons for this most probably lie in the Mesodinium spp. capture mechanism. As mentioned above, Mesodinium spp. use tentacles equipped with extrusomes (Lindholm et al. 1988). Extrusomes can most likely only be fired once, after which they will have to be replaced. In Mesodinium spp. this probably means that new extrusomes will have to be transported to the tip of the tentacle. This process will put a maximum limit on the number of capture attempts made by the ciliate and may thus explain our results.

\section{Effects of light on growth and ingestion by Mesodinium pulex}

Mesodinium pulex displayed considerably higher growth rates in the light (using a $14 \mathrm{~h}$ light:10 h dark cycle) compared to the dark, irrespective of prey concentration (Fig. 4). This may suggest that it is mixotrophic and that it gains a considerable input in terms of carbon from photosynthesis. Rates of photosynthesis of $M$. pulex were $\sim 32$ pg C cell ${ }^{-1} \mathrm{~d}^{-1}$ in wellfed cultures, which is about 10 times lower than the rates measured in the predominantly photosynthetic mixotroph $M$. rubrum using the same techniques (Hansen \& Fenchel 2006). Using a growth efficiency of the carbon uptake due to photosynthesis of $50 \%$ in phototrophs (Hansen et al. 2000), this suggests that 16 pg $C$ will be available for $M$. pulex growth per day. For comparison, a $M$. pulex cell contains $\sim 210$ pg C (Table 3). The maximum growth rate of $M$. pulex in the light was $\sim 1.4 \mathrm{~d}^{-1}$ or 2 doublings per day (Fig. 4B). This means that the expected growth increase due to photosynthesis of a well-fed $M$. pulex culture is less than $4 \%$. Thus, the increased growth rates in $M$. pulex in the light were by and large due to increased ingestion rates in the light (Fig. 4).

The finding of increased ingestion and growth rates in Mesodinium pulex in the light is not unique among heterotrophic protists, although very little information is presently available. Elevated ingestion and growth rates in the light compared to in the dark (or very low irradiance levels; i.e. $\leq 20 \mu \mathrm{mol}$ photons $\mathrm{m}^{-2} \mathrm{~s}^{-1}$ ) have previously been shown for a heterotrophic dinoflagellate, Gymnodinium sp. (Skovgaard 1998), and 2 ciliates: Coxliella sp. and Strombidinopsis acumicatum (Strom 2001). 
Table 3. Mesodinium pulex and Heterocapsa rotundata. Cell volumes ( \pm SE), estimated spherical diameter (ESD) and estimated cell carbon contents $( \pm \mathrm{SE})$ of $M$. pulex (well fed) and $H$. rotundata cultured in f/20 medium at an irradiance of $100 \mu$ mol photons $\mathrm{m}^{-2} \mathrm{~s}^{-1}$ and in the dark $(\mathrm{n}=20)$. Carbon content was estimated using the equations given by Menden-Deuer \& Lessard $(2000)$ : pg C cell ${ }^{-1}=0.76 \times \operatorname{vol}^{0.819}$ for $H$. rotundata and pg C cell ${ }^{-1}=0.216 \times \operatorname{vol}^{0.939}$ for $M$. pulex

\begin{tabular}{|llccc|}
\hline Irradiance & Species & $\begin{array}{c}\text { Cell volume } \\
\left(\mu \mathrm{m}^{3}\right)\end{array}$ & $\begin{array}{c}\text { ESD } \\
(\mu \mathrm{m})\end{array}$ & $\begin{array}{c}\text { Estimated carbon content } \\
\left(\mathrm{pg} \mathrm{C} \mathrm{cell}^{-1}\right)\end{array}$ \\
\hline \multirow{2}{*}{$100 \mu \mathrm{mol}$ photons $\mathrm{m}^{-2} \mathrm{~s}^{-1}$} & Mesodinium pulex & $1511 \pm 100$ & 13.7 & $208 \pm 13$ \\
& Heterocapsa rotundata & $117 \pm 9.3$ & 5.9 & $37 \pm 2.4$ \\
\multirow{2}{*}{ Dark } & Mesodinium pulex & $1432 \pm 92$ & 13.5 & $198 \pm 12$ \\
& Heterocapsa rotundata & $89 \pm 6.1$ & 5.4 & $30 \pm 1.7$ \\
\hline
\end{tabular}

Effects of light on ingestion and growth can be due both to direct effects of light on digestion rates and to indirect effects on food quality. Our growth and grazing experiments were not designed to differentiate between direct and indirect light effects, such as prey quality, or prey carbon content etc. However, Strom (2001) found a direct positive effect of light on the ingestion rates of 2 ciliate species, which increased by a factor of 2 to 7 at all irradiances $\geq 20 \mu \mathrm{mol}$ photons $\mathrm{m}^{-2} \mathrm{~s}^{-1}$, using short-term incubations (min) and fluorescently labeled algae (FLA) as prey. Thus, although very few data are available on light effects on ingestion and growth of heterotrophic ciliates, these data tend to suggest that our observations of increased ingestion and growth rates in the light can at least partly be explained by direct light effects on ingestion rates. What causes the increased ingestion rates in the light? Previous studies on the topic have suggested 'light aided' digestion of prey (Skovgaard 1998, Strom 2001). This is not unlikely because it is well established that dissolved organic matter is photochemically degradable (reviewed by Moran \& Zepp 1997). No data are however available on the effect of light on digestion rates in heterotrophic protists, apart from those of Strom (2001), who found a 40-fold increase in loss of food vacuoles (a proxy for digestion rate) of the heterotrophic dinoflagellate Noctiluca scintillans in the light compared to in the dark, when fed algal prey. More research on this topic is required to determine if this might be a general phenomenon among heterotrophic protists.

\section{Survival response in the light and in the dark}

Mesodinium pulex cultures which were allowed to deplete their prey to very low cell concentrations displayed very low rates of photosynthesis (Table 2). Also, when $M$. pulex was subjected to starvation, it survived better in the dark than in the 2 light treatments in our experiments. Thus, we can reject our hypothesis that photosynthesis in the light slows down mortalities compared to in the dark. Previous studies of survival responses of algivorous heterotrophic protists (2 ciliates and 1 dinoflagellate) have not been able to demonstrate any differences between light and dark treatments (Skovgaard 1998, Strom 2001). So why does M. pulex differ so much from the other species tested?

Mesodinium pulex is known to ingest prey of its own size (i.e. the ciliate Metanophrys sp., Dolan \& Coats 1991) and has very recently been shown to be cannibalistic ( $\varnothing$. Moestrup et al. unpubl.). None of the species tested by Skovgaard (1998) and Strom (2001) have been reported to be cannibalistic. Thus, if $M$. pulex indeed eats its own kind when starved, and if ingestion and digestion rates in the light are higher compared to those in the dark, this may explain the higher mortality rates observed in the light. This question would be worth studying in much more detail.

\section{Can Mesodinium pulex be considered a mixotrophic species?}

The estimated growth increase due to photosynthesis in Mesodinium pulex in the present study was less than $4 \% \mathrm{~d}^{-1}$ and the observed growth increase in the light could be explained by increased ingestion rates in the light compared to in the dark. Also, we found no evidence that $M$. pulex could survive better in the light compared to in the dark; in fact this ciliate survived better in the dark. Thus, we have no proof that photosynthesis is 'nutritious' for $M$. pulex. Therefore, on the basis of the existing data, we have to consider M. pulex a heterotrophic species, where the prey inside the food vacuoles is photosynthetically active for a short period of time.

The maximum growth rates of Mesodinium pulex obtained in the present study are comparable to growth rates reported for other marine planktonic ciliates and heterotrophic dinoflagellates fed nanophytoplankton at a temperature of $15^{\circ} \mathrm{C}$ (Hansen et al. 2000). In the experiments where Heterocapsa rotundata was used as prey, threshold prey concentrations for $M$. 
pulex were between 10 and 40 cells ml ${ }^{-1}$, equivalent to $0.3-1.5 \mu \mathrm{g} \mathrm{C} \mathrm{l}^{-1}$, which is lower than previously reported for heterotrophic dinoflagellates and ciliates feeding on nanophytoplankton (typically around 6 to $17 \mu \mathrm{g} \mathrm{C}^{-1}$ for optimally sized prey; Jakobsen \& Hansen 1997). In the experiments with other types of prey, threshold prey concentrations were much higher.

The ability to slow down metabolism is well known among ciliates and heterotrophic dinoflagellates (see discussion in Jakobsen \& Hansen 1997). We observed that Mesodinium pulex could survive for 12 to $16 \mathrm{~d}$ depending upon light conditions, which corresponds to between 28 and 34 times its minimum generation time. This is a long time compared to planktonic ciliates, which can usually only survive for 2 to 4 times their minimum generation time (Fenchel 1989, Montagnes 1996, Jakobsen \& Hansen 1997). Benthic ciliates, on the other hand, which live around the sediment-water interphase, are known to be much more resistant to starvation. Some species can even survive for up to 40 times their minimum generation time (Fenchel 1990). Thus, in terms of resistance to starvation, M. pulex are much more like benthic ciliates. This fits well with the fact that $M$. pulex is often detected in sediment surface samples (Foissner et al. 1999).

\section{CONCLUSIONS}

Many different groups of protists capture single prey items using a variety of capture mechanisms. Dinoflagellates often use capture filaments, while haptophytes often use the haptonema for prey capture (Kawachi et al. 1991, Hansen \& Calado 1999). The cyclotrichs, including Mesodinium spp., use extrusomes for prey capture. Our knowledge of the mechanisms of prey selection in many protist predators which rely on single prey capture is very limited. While some studies indicate chemical as well as mechanical cues for detection of prey items (Jacobson \& Anderson 1986, Hansen \& Calado 1999, Naustvoll 2000a,b, Jakobsen et al. 2006, Riisgaard \& Hansen 2009), the role of capture success of such predator types is largely unexplored (e.g. Jakobsen et al. 2006). In M. pulex, we show that prey species with a similar size are ingested at very different rates, suggesting that the cell surface of the prey is important in avoiding being consumed by predators like Mesodinium spp. Much more work is needed on this topic and its significance in species succession, prey/predator population dynamics and carbon flow in marine waters.

An unexpected result of our study was the apparent role of light in ingestion and growth of Mesodinium pulex. Our hypothesis of a significant role of photosynthesis in the growth and survival of $M$. pulex was rejected. Thus, our data instead support the suggestions by Skovgaard (1998) and Strom (2001) that light plays a direct role in the digestion of prey by heterotrophic protists. Most studies dealing with the growth and grazing rates of heterotrophic ciliates have been carried out in complete darkness or at very low levels of irradiance $\left(<25 \mu \mathrm{mol}\right.$ photons $\mathrm{m}^{-2} \mathrm{~s}^{-1}$; Verity 1991, Montagnes et al. 1996, Jeong et al. 1999, Gismervik 2005). The reasons for the incubation of such experiments at low or no light among most researchers have primarily been reduction of prey growth rate during the experiments and the fact that light has not been considered an important factor for grazing of entirely heterotrophic protists. If light turns out to play an important role in the digestion of prey by protists in general it may have considerable implications for the application of ingestion data from laboratory experiments to field abundances of protists aiming to estimate the role of protists in microbial food webs (e.g. Hansen et al. 1997). Thus, work on this topic is strongly urged.

Acknowledgements. We are indebted to H. H. Jakobsen, Ø. Moestrup and L. Garcia-Cuetos for comments and suggestions, which improved this paper significantly. We thank $\mathrm{H}$. $\mathrm{H}$. Jakobsen for the use of this isolate of Mesodinium pulex. This study was supported by the Danish Research Council to P.J.H., grant no. 272-06-0485, and a PhD grant from Rajamangala University of Technology Srivijaya, Thailand, to W.T.

\section{LITERATURE CITED}

Al-Rasheid KAS (2001) New records of interstitial ciliates (Protozoa Ciliophora) from the Saudi coasts of the Red Sea. Trop Zool 14:133-156

Bass D, Brown N, Mackenzie-Dodds J, Dyal P, NierzwickiBauer SA, Vepritskiy AA, Richards TA (2009) A molecular perspective on ecological differentiation and biogeography of cyclotrichiid ciliates. J Eukaryot Microbiol 56: $559-567$

Calkins GN (1902) Marine protozoa from Woods Hole. Bull US Fish Comm 21(year 1901):415-468

Carrias JF, Amblard C, Bourdier G (1996) Protistan bacterivory in an oligomesotrophic lake: importance of attached ciliates and flagellates. Microb Ecol 31:249-268

Claparède E, Lachmann J (1858) Études sur les infusoires et les rhizopodes. In: Mémoirs de l'Institut National Genevois, Vol 5, année 1857. Kessmann, Geneva, p 1-260, plates 1-13

Claparède E, Lachmann J (1859) Études sur les infusoires et les rhizopodes. In: Mémoirs de l'Institut National Genevois, Vol 6, année 1858. Kessmann, Geneva, p 261482, plates $1-24$

Dolan JR, Coats DW (1991) A study of feeding in predacious ciliates using prey ciliates labeled with fluorescent microspheres. J Plankton Res 13:609-627

Fenchel T (1989) Adaptations to a feast and famine existence in protozoa. In: Weiser W, Gnaier G (eds) Energy transformation in cells and organisms. Georg Thieme Verlag, Stuttgart, p 290-295 
Fenchel (1990) Adaptive significance of polymorphic life cycle in protozoa: responses to starvation and refeeding in two species of marine ciliates. J Exp Mar Biol Ecol 136: 159-177

Foissner W, Berger H, Schaumburg J (1999) Identification and ecology of limnetic plankton ciliates. Informationsberichte des Bayer. Landesamtes für Wasserwirtschaft, Heft 3/99, Munich

Garcia-Cuetos L, Moestrup Ø, Hansen PJ, Daugbjerg N (2010) The toxic dinoflagellate Dinophysis acuminata harbors permanent chloroplasts of cryptomonad origin, not kleptochloroplasts. Harmful Algae 9:25-38

Gismervik I (2005) Numerical and functional response of choreo- and oligotrich planktonic ciliates. Aquat Microb Ecol 40:163-173

Guillard RRL (1975) Culture of phytoplankton for feeding marine invertebrate. In: Smith WL, Chanley $\mathrm{MH}$ (eds) Culture of marine invertebrate animals. Plenum Press, New York, NY, p 29-60

Guillard RRL (1983) Culture of phytoplankton for feeding invertebrate animals. In: Berg CJ (ed) Culture of marine invertebrates. Hutchinson Ross, Stroudsberg, PA, p 123-128

Gustafson DE Jr, Stoecker DK, Johnson MD, Van Heukelem WF, Sneider K (2000) Cryptophyte algae are robbed of their organelles by the marine ciliate Mesodinium rubrum. Nature 405:1049-1052

Hamburger C, von Buddenbrock W (1911) XIII. Nordische Ciliata mit Anschluss der Tintinnoidea. Nordisches Plankton, Zool. Teil. Lipsius und Tischer, Kiel und Leipzig

> Hansen PJ, Calado A (1999) Phagotrophic mechanisms and prey selection in free-living dinoflagellates. J Eukaryot Microbiol 46:382-389

Hansen PJ, Fenchel T (2006) Mesodinium rubrum harbours a permanent endosymbiont. Mar Biol Res 2:169-177

> Hansen PJ, Hansen B, Bjørnsen PK (1997) Zooplankton grazing and growth: scaling within the size range $2 \mathrm{~mm}$ to $2000 \mathrm{~mm}$. Limnol Oceanogr 42:687-704

Hansen PJ, Skovgaard A, Glud RN, Stoecker DK (2000) Physiology of the mixotrophic dinoflagellate Fragilidium subglobosum. II. Effects of time scale and prey concentration on photosynthetic performance. Mar Ecol Prog Ser 201: 137-146

Hillebrand H, Durselen CD, Kirschtel D, Pollingher U, Zohary $\mathrm{T}$ (1999) Biovolume calculation for pelagic and benthic microalgae. J Phycol 35:403-424

> Jacobson DM, Anderson DM (1986) Thecate heterotrophic dinoflagellates: feeding behavior and mechanisms. J Phycol 22:249-258

Jakobsen HH, Hansen PJ (1997) Prey size selection, grazing and growth response of the small heterotrophic dinoflagellate Gymnodinium sp. and the ciliate Balanion comatum - a comparative study. Mar Ecol Prog Ser 158:75-86

> Jakobsen HH, Strom SL (2004) Circadian cycles in growth and feeding rates of heterotrophic protist plankton. Limnol Oceanogr 49:1915-1922

Jakobsen HH, Everett LM, Strom SL (2006) Hydromechanical signaling between the ciliate Mesodinium pulex and motile protist prey. Aquat Microb Ecol 44:197-206

> Jeong HJ, Shim JH, Lee CW, Kim JS, Koh SM (1999) Growth and grazing rates of the marine planktonic ciliate Strombidinopsis sp. on red-tide and toxic dinoflagellate. J Eukaryot Microbiol 46:69-76

> Johnson MD, Stoecker DK (2005) Role of feeding in growth and photophysiology of Myrionecta rubra. Aquat Microb Ecol 39:303-312
Johnson MD, Oldach D, Delwiche CF, Stoecker DK (2007) Retention of transcriptionally active cryptophyte nuclei by the ciliate Myrionecta rubra. Nature 445:426-428

Kahl A (1935) Die Tierwelt Deutschlands und der angrenzenden Meeresteile. 30. Urtiere oder Protozoa. I. Wimpertiere oder Ciliata (Infusoria). 4. Peritricha und Chonotricha. Gustav Fischer Verlag, Jena, p 651-886

Kawachi M, Inouye I, Madea O, Chihara M (1991) The haptonema as a food-capturing device-observations on Chrysochromulina hirta (Prymnesiophyceae). Phycologia 30:563-573

Lindholm T (1985) Mesodinium rubrum - a unique photosynthetic ciliate. Adv Aquat Microbiol 3:1-48

> Lindholm T, Lindroos P, Mörk AC (1988) Ultrastructure of the photosynthetic ciliate Mesodinium rubrum. Biosystems 21:141-149

Lohmann H (1908) Untersuchungen zur Feststellung des vollständigen Gehaltes des Meeres an Plankton. Wiss Meeresunters Abt Kiel (N.F.) 10:129-370

Lynn DH (2008) The ciliated protozoa-characterization, classification, and guide to the literature. Springer Science, New York, NY

> Menden-Deuer SM, Lessard EJ (2000) Carbon to volume relationships for dinoflagellates, diatoms and other protist plankton. Limnol Oceanogr 45:569-579

Montagnes DJS (1996) Growth responses of planktonic ciliates in the genera Strobolidium and Strombidium. Mar Ecol Prog Ser 130:241-254

> Montagnes DJS, Berger JD, Taylor FJR (1996) Growth rate of the marine planktonic ciliate Strombidinopsis cheshiri Snyder and Ohman as a function of food concentration and interclonal variability. J Exp Mar Biol Ecol 206:121-132

Moran MA, Zepp RG (1997) Role of photoreactions in the formation of biologically labile compounds from dissolved organic matter. Limnol Oceanogr 42:1307-1316

> Myung G, Yih W, Kim HS, Park JS, Cho BC (2006) Ingestion of bacterial cells by the marine photosynthetic ciliate Myrionecta rubra. Aquat Microb Ecol 44:175-180

> Naustvoll LJ (2000a) Prey size spectra and food preferences in thecate heterotrophic dinoflagellates. Phycologia 39: $187-198$

Naustvoll LJ (2000b) Prey size spectra and food preferences in naked heterotrophic dinoflagellates. Phycologia 39: 448-455

> Park JS, Myung G, Kim HS, Cho BC, Yih W (2007) Growth responses of the marine photosynthetic ciliate Myrionecta rubra to different cryptomonad strains. Aquat Microb Ecol 48:83-90

Parsons TR, Maita Y, Lalli CM (1984) A manual of chemical and biological methods for seawater analysis. Pergamon Press, Oxford

> Riisgaard K, Hansen PJ (2009) Role of food uptake for photosynthesis, growth and survival of the mixotrophic dinoflagellate Dinophysis acuminata. Mar Ecol Prog Ser 381:51-62

> Sakaguchi M, Murakami H, Suzaki T (2001) Involvement of a 40-kDa glycoprotein in food recognition, prey capture, and induction of phagocytosis in the protozoon Actinophrys sol. Protist 152:33-41

Skovgaard A (1998) Role of chloroplast retention in a marine dinoflagellate. Aquat Microb Ecol 15:293-301

Skovgaard A, Hansen PJ, Stoecker DK (2000) Physiology of the mixotrophic dinoflagellate Fragilidium subglobosum. I. Effects of phagotrophy and irradiance on photosynthesis and carbon content. Mar Ecol Prog Ser 201:129-136

Smith M, Hansen PJ (2007) Interaction between Mesodinium rubrum and its prey: importance of prey concentration, irradiance and pH. Mar Ecol Prog Ser 338:61-70 
Stein F (1863) Neue Infusorienformen in der Ostsee. Amtliche Berichte deutscher Naturforscher und Ärzte in Karlsbad, 37. Versammlung in September 1862: 161-162, 165-166

Stein F (1867) Der Organismus der Infusionsthiere nach eigenen Forschungen. II. Abtheilung. 1. Darstellung der neuesten Forschungsergebnisse über Bau, Fortpflanzung und Entwicklung der Infusionsthiere. 2. Naturgeschichte der heterotrichen Infusorien. Engelmann, Leipzig. III-VI and 1-355

Stoecker DK, Silver MW, Michaels AE, Davis LH (1988) Obligate mixotrophy in Laboea strobila, a ciliate which retains chloroplasts. Mar Biol 99:415-423

Stokes AC (1887) Notices of new American freshwater infusoria. J R Microsc Soc, year 1887:35-40

Strom SL (2001) Light-aided digestion, grazing and growth in herbivorous protists. Aquat Microb Ecol 23:253-261

> Tamar H (1986) Four marine species of Mesodinium (Ciliophora: Mesodiniidae) I. Mesodinium velox. Trans Am Microsc Soc 105:130-140

Editorial responsibility: Robert Sanders,

Philadelphia, Pennsylvania, USA
Tamar H (1992) Four marine species of Mesodinium (Ciliophora: Mesodiniidae) II. Mesodinium pulex Clap \& Lachm, 1858. Arch Protistenkd 141:284-303

Tang KW, Jakobsen HH, Visser AW (2001) Phaeocystis globosa (Prymnesiophyceae) and the planktonic food web: feeding, growth, and trophic interactions among grazers. Limnol Oceanogr 46:1860-1870

Verity PG (1991) Measurement and simulation of prey uptake by marine planktonic ciliates fed plastidic and aplastidic nanoplankton. Limnol Oceanogr 36:729-750

- Wootton EC, Zubkov MV, Jones DH, Jones RH, Martel CM, Thornton CA, Roberts EC (2007) Biochemical prey recognition by planktonic protozoa. Environ Microbiol 9: $216-222$

Yih W, Kim HS, Jeong HJ, Myung G, Kim YG (2004) Ingestion of cryptophyte cells by the marine photosynthetic ciliate Mesodinium rubrum. Aquat Microb Ecol 36: $165-170$

Submitted: March 9, 2010; Accepted: August 30, 2010

Proofs received from author(s): October 27, 2010 